\title{
Groundwater lowering and stream incision rates in the Central Appalachian Mountains of West Virginia, USA
}

\author{
Gregory S. Springer ${ }^{1}$, Holly A. Poston ${ }^{1}$, Ben Hardt ${ }^{2}$ and Harold D. Rowe ${ }^{3}$ \\ ${ }^{1}$ Department of Geological Sciences, Ohio University, Athens, OH 45701, USA \\ ${ }^{2} 12201$ Sunrise Valley Dr., MS 926A, Reston, VA 20192, USA \\ ${ }^{3}$ Bureau of Economic Geology, University Station, Box X, University of Texas at Austin, TX 78713-8924, USA
}

\begin{abstract}
Surface channel incision rates are of broad geomorphological interest because they set the boundary conditions for landscape change by affecting changes in local relief and hillslope angles. We report groundwater table lowering rates associated with subsurface Buckeye Creek and the surface channel of Spring Creek in southeastern West Virginia, USA. The mountainous watersheds have drainage areas of $14 \mathrm{~km}^{2}$ and $171 \mathrm{~km}^{2}$, respectively. The lowering rates are derived from $\mathrm{U} / \mathrm{Th}$-dating of stalagmites and the paleomagnetostratigraphy of clastic sediments in Buckeye Creek Cave. The oldest stalagmites have a minimum age of $0.54 \mathrm{Ma}$ and we use a minimum age of $0.778 \mathrm{Ma}$ for clastic cave sediments deposited during a period of reversed magnetic polarity. The water table at Buckeye Creek has lowered at a rate of $\leq 40 \mathrm{~m} \mathrm{Ma}^{-1}$. Based on the relative elevations of Buckeye and Spring creeks, the water table at Spring Creek has lowered at a rate of $\leq 47 \mathrm{~m} \mathrm{Ma}^{-1}$. These values are consistent with previously published rates obtained from caves in the region, although those rates were reported as surface channel incision rates, based on the assumption local groundwaters drained to the surface channel of interest. However, the rates we report are almost certainly not simple bedrock incision rates because of karst processes acting within the cave and surrounding, well-developed fluviokarst (e.g., stream capture). Caveats aside, incision rates of $\leq 47 \mathrm{~m} \mathrm{Ma}^{-1}$ now appear typical of landscapes of the Appalachian Mountains and Plateau.
\end{abstract}

Keywords: $\quad$ cave, karst, river incision, incision rate, Appalachian Mountains

Received 15 September 2014; Revised 5 December 2014; Accepted 15 December 2014

Citation: $\quad$ Springer G.S., Poston H.A., Hardt B. and Rowe H.D., 2014. Groundwater lowering and stream incision rates in the Central Appalachian Mountains of West Virginia, USA. International Journal of Speleology, 44 (1), 99-105. Tampa, FL (USA) ISSN 0392-6672

http://dx.doi.org/10.5038/1827-806X.44.1.9

\section{INTRODUCTION}

Surface channel incision rates are of broad interest to geomorphologists because they strongly influence landscape development and denudation rates by setting the boundary conditions for hillslope angles and relief (Burbank et al., 1996). However, incision may not be continual and short- and long-term changes in incision rates may be affected by climate or other perturbations through their effects upon stream discharges, sediment supply, and regional base-level elevations. Thus, long-term histories of stream incision may offer insights into events not readily preserved in the geological record (Yang et al., 2011). Incision rates can be calculated by age-dating alluvial and bedrock (strath) terraces, but these may be too few or too difficult to date in erosional environments, which has led various workers to use cave evolution as a proxy for surface channel lowering (Granger et al., 1997; Springer et al., 1997; Granger et al., 2001; Anthony and Granger, 2007). Caves can shield sedimentary deposits from surface processes for millions of years, while cave morphologies give context to those deposits by serving as records of past water table elevations. If one assumes water table elevations reflect local minima in surface channel elevations, a water table history can be used to reconstruct surface channel histories and incision rates (Granger et al., 2001). This assumption is inherent in the studies cited above and may not be true where the surface stream is itself subject to significant subsurface piracy. We consider just such a case and report two independently derived groundwater table lowering rates.

Cave deposit ages can be calculated using multiple techniques and here too interpretations are dependent upon key assumptions. The greatest uncertainty arises from our inability to age-date cave passages, which are erosional voids, as opposed to the deposits they contain; a deposit can be substantially younger than its host cave passage (Sasowsky, 1998; Stock et al., 2005). 
Thus, deposit ages provided a minimum age for the enclosing passages and must be interpreted as such. This applies to the two dating methods we utilize, U-Th dating of stalagmites and paleomagnetostragraphy, with the former prone to substantially underrepresenting cave ages because stalagmites may have grown long after a stream passage was abandoned (Stock et al., 2005). Nonetheless, they provide a minimum age for the enclosing passage and a maximum incision rate.

Ages are estimated using paleomagnetostragraphy by comparing the magnetization of cave deposits to established histories of the Earth's magnetic field. This is possible because magnetic particles may align with the Earth's magnetic field as they were deposited from suspended sediments. Upon deposition, the magnetically oriented grains preserve a depositional remnant magnetization (DRM), which can be isolated and measured in samples to determine whether the sediment was deposited when the Earth possessed a normal or reversed polarity field (Schmidt, 1982). The current period of normal polarity has persisted since $0.778 \mathrm{Ma}$ (Singer \& Pringle, 1996), which is generally inferred to be the minimum age of detrital, reversed DRM sediments in caves. This may be a significant underestimate of the age of cave sediments and it is very difficult to determine whether sediments possessing a normal DRM are from the current normal episode (Bruhnes) or some previous normal period (Stock et al., 2005). We report all reverse DRM samples as being $>0.778 \mathrm{Ma}$ in age and make no assumptions about the ages of samples preserving a normal DRM.

In general, cave deposits are the most practical means of estimating incision rates in the region of our study. The rugged watersheds we examine, Spring Creek and Buckeye Creek, are in southeastern West Virginia in the central Appalachians and have moderate to high relief (200-1000 m) with narrow valley floors and comparatively few terraces. Spring Creek is a tributary of the Greenbrier River for which Shank and Sasowsky (2001) report a long-term incision rate of $40 \mathrm{~m} \mathrm{Ma}^{-1}$, based on the paleomagnetostratigraphy of sediments in a cave adjacent to the Greenbrier. The Greenbrier rate broadly similar to regional studies, including a rate of $\sim 27 \mathrm{~m} \mathrm{Ma}^{-1}$ for the New River (Granger et al., 1997), for which the Greenbrier River is a tributary. The New River values were obtained using cosmogenic isotope dating of cave sediments and is lower than the $59 \mathrm{~m} \mathrm{Ma}^{-1}$ rate reported for the Cheat River in northern West Virginia (Springer et al., 1997). The incision rates of the Cheat, Greenbrier, and New Rivers are broadly similar to those of the Cumberland and Green rivers of Kentucky and Tennessee, respectively, but the incision histories of the latter two rivers are much better understood (Granger et al., 2001; Anthony \& Granger, 2007). Incision rapidly accelerated in those rivers after formation of the Ohio River at $\sim 1.5 \mathrm{Ma}$ (Granger et al., 2001). The periods of rapid incision occurred as knickpoints migrated upstream and lowered local and regional base levels (Anthony \& Granger, 2007), a process which also may have occurred within the New River watershed, a major headwater tributary of the Ohio. The results we report do not have direct bearing on this question because our cave deposits are comparatively young $(<1 \mathrm{Ma})$. As a result, we focus our analysis on local phenomena, including processes acting only or entirely within the local karst (i.e., autogenic).

\section{STUDY AREA}

We report incision rates for Buckeye and Spring Creeks in southeastern West Virginia. Spring Creek is a large perennial stream draining the eastern margins of the Appalachian Plateau (Fig. 1). The region is tectonically inactive (Miller et al., 2013), although local relief can exceed 500 meters. Spring Creek has a total drainage area is $363 \mathrm{~km}^{2}$, of which $171 \mathrm{~km}^{2}$ is upstream of the stream segment we consider (Dasher $\&$ Balfour, 1994). The creek is a major tributary of the Greenbrier River, the local base level stream. The Spring Creek watershed includes the $14-\mathrm{km}^{2}$ Buckeye Creek watershed, whose center is a large closed depression from which the basin's waters exit via Buckeye Creek Cave (BCC). The $1.6 \mathrm{~km}$ long, underground path is entirely traversable, ending at a spring on the banks of Spring Creek (Fig. 2). The active stream passage is the lowest of four tiers or passage levels, the highest of which is $30 \mathrm{~m}$ above the modern cave stream. The abandoned tiers contain clastic stream sediments and stalagmites, some of which were sampled for this study. Dasher and Balfour (1994) described the 7-km long cave system in detail and modern channel hydraulics are analyzed in Springer et al. (2003) and Springer (2004).

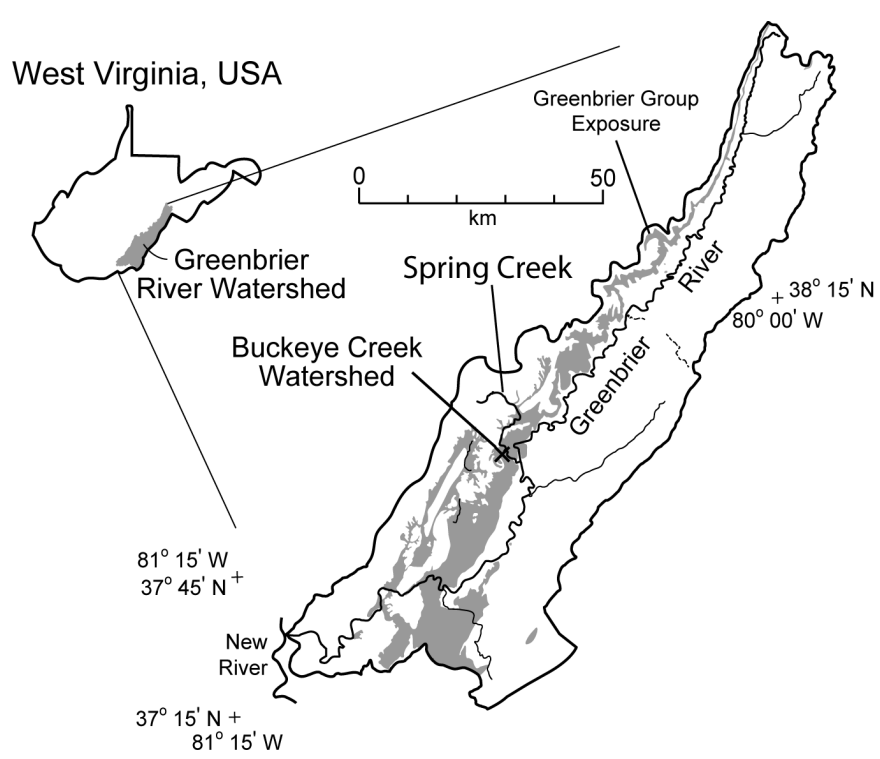

Fig. 1. Locations of Buckeye and Spring Creeks within West Virginia and the Greenbrier River watershed. The shaded portions of the watershed map represent outcrops of the Greenbrier Group (limestones), including the outcrops across which Spring Creek flows.

Spring Creek descends from the Allegheny Front where local peaks are 1250 masl. The stream has a bed elevation of 579 masl at Buckeye Creek. The bedrock channel is perched at BCC atop the lower Pickaway Formation of the Greenbrier Group, a mixed unit of calcareous shales, siltstones, and limestones, and the underlying, shale-dominated Taggard Formation. However, the riverbed is normally dry between 4 and 10 kilometers upstream where the 


\section{Buckeye Creek Cave, West Virginia}

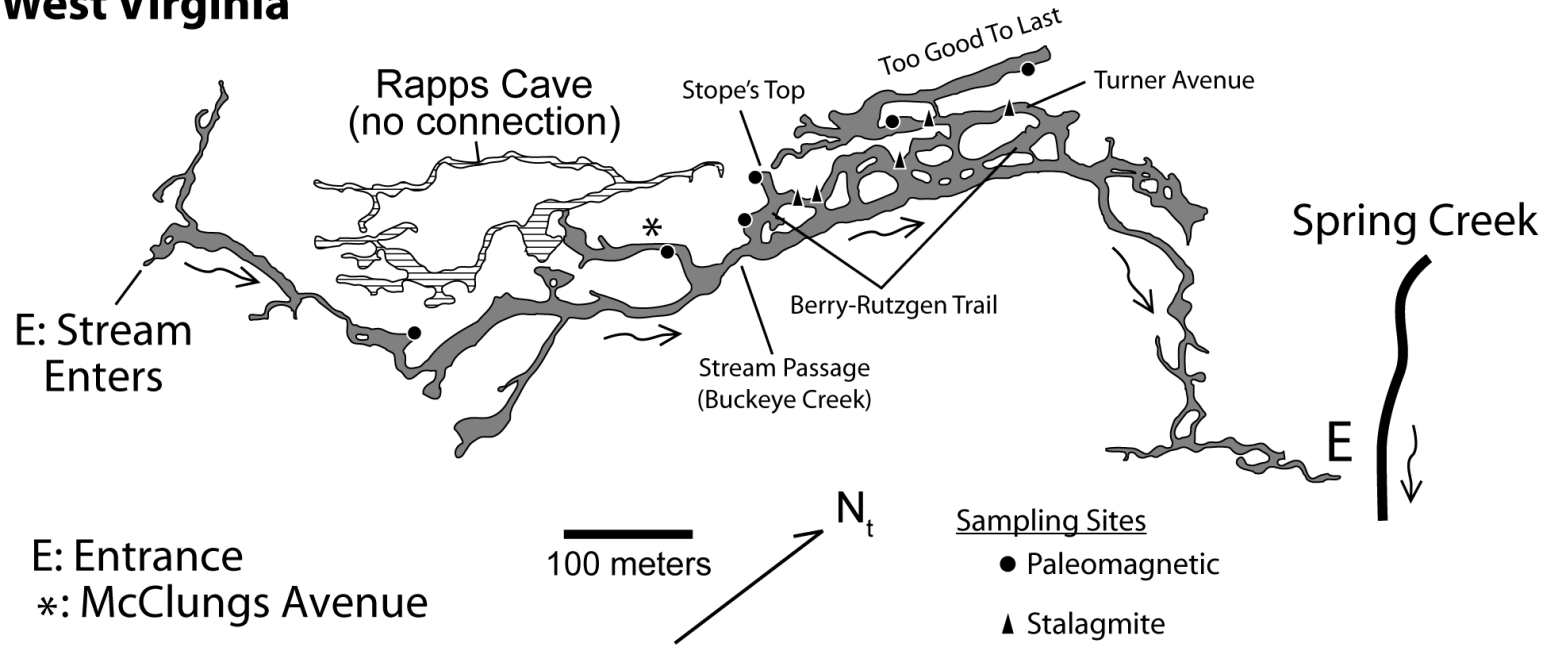

Fig. 2. A plan view of Buckeye Creek Cave. The southern most passage is the lowest tier and contains the cave stream. All other passages are abandoned upper level stream passages. Paleomagnetic sampling locations are shown as filled circles. Narrow triangles mark stalagmite collection points. The map is adapted from a cave map published in Dasher and Balfour (1994).

Passage names are from the cave map.

bed is developed in cave-forming limestones of the Union Formation. The water diverted underground reappears downstream of $\mathrm{BCC}$ in several large springs (Dasher \& Boyer, 2000), having passed through the Taggard Formation via comparatively deep phreatic flow. The perennial flow in Spring Creek adjacent to $\mathrm{BCC}$ is from nearby karstic tributaries, also perched on the Pickaway Formation, and not the headwaters of Spring Creek (Balfour, pers. comm. June 2013).

Along this stream segment, the surface channel is within the Union and upper Pickaway Formations, which are highly caverniferous, containing $>150-\mathrm{km}$ of surveyed passages in caves tributary to Spring Creek (Dasher \& Boyer, 2000; Jones, 1997). The ephemeral Spring Creek segment currently found upstream of BCC is directly analogous to ancient Spring Creek at BCC before it had incised to its present position. Thus, it is possible BCC once fed a subsurface Spring Creek flowing within conduits well below the surface channel, but nonetheless at or near the water table.

\section{METHODS}

\section{Elevation data}

Incision rates are calculated using relative elevations of sample locations, the active bed of Buckeye Creek in the cave, and the bed of Spring Creek. In-cave distances and inclinations were measured simultaneously using a tripod-mounted laser device. A $450 \mathrm{~m}$ long loop yielded a vertical closure error of $1.2 \mathrm{~cm}$. Compass bearings was not measured. The elevation of the Spring Creek bed was determined by tying into a cave and surface survey conducted in the 1980s by George Dasher and the West Virginia Association for Cave studies (Dasher \& Balfour, 1994). Their surface survey was tied directly to the cave survey and included the channel of Spring Creek. Their in-cave loops yielded vertical closures of less than $10 \mathrm{~cm}$, which translates to $\leq 1 \%$ uncertainty in the relative elevations of sample locations and stream beds.

\section{U/Th samples and ages}

Stalagmites were collected between 2003 and 2012. Individual stalagmites were collected whole from the three lowest cave levels: active stream passage (SP), Berry-Rutzgen Trail (BRT), and Turner Avenue (TA) (Fig. 2). The latter two names follow Dasher and Balfour (1994). The stalagmites were collected in conjunction with a paleoclimate study and, except for sample BCC-027, dates were obtained to establish age chronologies for stable isotope transects $\left(\delta^{13} \mathrm{C}\right.$ and $\delta^{18} \mathrm{O}$ ). Herein, we report basal ages for individual stalagmites and the age of the top of BCC-027. Where multiple ages were obtained, dates are in stratigraphic order, once again excepting BCC-027 (discussed below). Individual stalagmites were sliced along their growth axis into halves for sub-sampling. Ages are not reported from stalagmites whose interior calcite lacks growth laminations, probably due to post-depositional recrystallization.

Radiometric age constraints were provided by $\mathrm{U} / \mathrm{Th}$ dating techniques developed for carbonates (Broecker, 1963) and adapted for measurement on an inductively coupled plasma mass spectrometer (Edwards et al., 1987; Shen et al., 2002) at the University of Minnesota. Calcite powder was sampled using a dental drill with a 0.9 -mm diameter tungstencarbide drill bit. Chemical procedures for isolation of uranium and thorium were run along with a chemical blank, which was used to correct the final measurements. Age determinations were made using $\mathrm{U} / \mathrm{Th}$ disequilibrium measurements conducted on a Finnegan Neptune inductively coupled plasma mass spectrometer with a single MasCom multiplier using the decay constants of Cheng et al. (2009).

\section{Paleomagnetic ages}

Samples were collected in $8-\mathrm{cm}^{3}$, demagnetized plastic cubes (boxes) from unconsolidated, laminated sediments in abandoned stream passages (c.f., Sasowsky et al., 1995). The sampled silts are all interpreted to be former "mud banks" and slackwater sediments deposited by 
Buckeye Creek during floods. The sediments were firm and horizontal projections were carved using plastic knives from cleaned, freshly created exposures. Boxes were placed on the projections and the threedimensional orientation of the end face was measured using a Brunton by measuring the strike direction of the face, its left-right tilt, and its forward-backward tilt. These values were recorded before samples were severed from their exposure. An end cap was inserted on each box to completely and permanently enclose the samples in plastic.

The samples were collected and analyzed in 1993 during a pilot study, but were not reported until their use here. The samples were analyzed in a magnetically shielded room in the University of Pittsburgh Paleomagnetic Laboratory using a rock magnetometer. The process was automated with individual samples being mechanistically inserted into the 3-axis, superconducting magnetometer, sequentially rotated, and demagnetized on a step-wise basis. Demagnetization removes secondary magnetic imprints arising from postdepositional, magnetically-driven reorientation of grains, typically by the Earth's field (Schmidt, 1982; Sasowsky et al., 1995). The alternating field demagnetization was performed with field strengths of 0 to $120 \mathrm{mT}$. Among our samples, several yielded reverse polarity DRMs after demagnetization removed overprinted normal signals, as can be seen in orthogonal vector plots of sample field orientations in Fig. 3. It was sufficient for our purposes to determine whether the DRMs possessed normal, reverse, or indeterminate field orientations because our samples were collected from multiple sedimentary deposits.

\section{RESULTS}

\section{U/Th samples}

We report $\mathrm{U} / \mathrm{Th}$ ages from eight $\mathrm{BCC}$ stalagmites and paleomagnetic data from 16 clastic sediment samples ( 8 pairs). The U/Th ages span the modern to $>540,000$ years before the present, where present is defined as $1950 \mathrm{AD}$. In general, young BCC stalagmites contain comparatively high concentrations of uranium and thorium (Hardt et al., 2010), probably because a 10-m thick shale caps the overlying hillside. U/Th ratios in older stalagmites are consistent with similarly high initial U concentrations. Reliable maximum ages could not be obtained from five stalagmites. The five stalagmites have growth-laminated calcite encased within a cmscale weathering rind whose calcite has a chalklike texture easily scraped off. These stalagmites were collected in their growth positions, suggesting the weathering rind is due to interactions with the cave atmosphere and, perhaps, recrystallization. Inactive stalagmites from which reliable ages were obtained often lack weathering rinds, but others possess mm-scale rinds of similar texture to the undatable stalagmites. Active stalagmites entirely lack weathering rinds. The smallest specimen, BCC027, yielded a questionable basal age of $539 \mathrm{ka}$, but an age of infinity closer to its tip remnant. The other four stalagmites also yielded extreme ages, so based on the sensitivity of the Neptune mass-spectrometer; we assign a minimum, rounded age of $0.540 \mathrm{Ma}$ to the five stalagmites.

Table 1. Paleomagnetism results for clastic sediments collected in Buckeye Creek Cave. Locations refer to cave passages discussed in the text and shown in Fig. 2.

Average primary

\begin{tabular}{lccccc} 
Location & $\begin{array}{c}\text { Paleomag. } \\
\text { sample }\end{array}$ & P.R.M. & $\begin{array}{c}\text { Inclination } \\
\mathbf{( \bullet}^{*}\end{array}$ & $\begin{array}{c}\text { Declination } \\
(\mathbf{0})\end{array}$ & $\begin{array}{c}\text { Initial } \\
\text { intensity } \\
(\mathbf{J} / \mathbf{m})\end{array}$ \\
\hline Active Stream Passage & 007 & $\mathrm{~N}$ (normal) & 44.6 & 340 & $9.32 \times 10^{-6}$ \\
Active Stream Passage & 008 & $\mathrm{~N}$ & 41.6 & 359 & $8.74 \times 10^{-6}$ \\
Active Stream Passage & 009 & $\mathrm{~N}$ & 23.5 & 3 & $7.45 \times 10^{-5}$ \\
Active Stream Passage & 010 & $\mathrm{~N}$ & 36.2 & 8 & $5.8 \times 10^{-5}$ \\
McClungs Avenue & 011 & $\mathrm{~N}$ & 59.6 & 350 & $2.57 \times 10^{-5}$ \\
McClungs Avenue & 012 & $\mathrm{~N}$ & 55.9 & 355 & $2.55 \times 10^{-5}$ \\
BRT & 015 & $\mathrm{~N}$ & 54.3 & 352 & $3.85 \times 10^{-5}$ \\
BRT & 016 & $\mathrm{~N}$ & 25.2 & 10 & $2.4 \times 10^{-5}$ \\
Stope's Top & 017 & $\mathrm{R}(\mathrm{reversed})$ & -48.9 & 185 & $9.93 \times 10^{-6}$ \\
Stope's Top & 018 & $\mathrm{R}$ & -2.4 & 198 & $3.47 \times 10^{-5}$ \\
TGTL & 019 & $\mathrm{R}$ & -34.1 & 185 & $1.39 \times 10^{-6}$ \\
TGTL & 020 & $\mathrm{R}$ & -43.6 & 203 & $4.41 \times 10^{-6}$ \\
TGTL & 021 & $\mathrm{R}$ & -45.9 & 191 & $1.61 \times 10^{-5}$ \\
TGTL & 022 & $\mathrm{R}$ & -45.1 & 224 & $2.29 \times 10^{-5}$ \\
Prism Canyon & 023 & $\mathrm{~N}$ & 49.6 & 354 & $3.08 \times 10^{-5}$ \\
Prism Canyon & 024 & $\mathrm{~N}$ & 25 & 353 & $2.46 \times 10^{-5}$ \\
\hline
\end{tabular}

\footnotetext{
* Primary remnant magnetization.
} 


\section{Paleomagnetic samples}

Six of 16 paleomagnetic samples displayed reversed primary remnant magnetizations after normal polarity overprints were removed (Table 1, Fig. 3). The three sample pairs were collected from the highest known cave level and all six samples display reversed primary magnetism. Two sample pairs were obtained from silt banks in the Too Good To Last Passage (TGTL) and the remaining pairs were obtained from Stope's Top, a fragment of the same passage exposed by collapse of underlying passages (Fig. 2). At Stope's Top, sediments had filled the river-right (south) side of the passage to its ceiling. A subsequent collapse exposed cut-and-fill gravels overlain by crossbedded sands, and capped by $\sim 2$ meters of laminated silt. The samples were collected from the silt, which is superficially similar that observed in TGTL.

Table 2. Groundwater lowering and incision rates calculated for Buckeye Creek. All rates are maximum values. The real incision rates are equal to or less than the numbers given.

\begin{tabular}{lcccc} 
Location & $\begin{array}{c}\text { Height above } \\
\text { stream (m) }\end{array}$ & $\begin{array}{c}\text { Minimum } \\
\text { age (years) }\end{array}$ & $\begin{array}{c}\text { Max. incision } \\
\text { rate (m/Ma) }\end{array}$ & Age control \\
\hline TGTL & 26.8 & 778,000 & 34 & Paleomag Samples 019-022 \\
Stope's Top & 29.9 & 778,000 & 38 & Paleomag Samples 017/018 \\
Prism Canyon & 24.4 & 540,000 & 45 & Stalagmite BCC-022 \\
Prism Canyon & 24.4 & 581,000 & 42 & Stalagmite BCC-024 \\
Prism Canyon & 24.4 & 628,000 & 39 & Stalagmite BCC-025 \\
Turner Avenue & 21.0 & 308,000 & 68 & Stalagmite BCC-011 \\
Turner Avenue & 21.0 & 298,000 & 71 & Stalagmite BCC-012 \\
BRT & 18.3 & 294,000 & 62 & Stalagmite BCC-013 \\
BRT & 18.3 & 108,700 & 168 & Stalagmite BCC-026 \\
BRT & 18.3 & 540,000 & 34 & Stalagmite BCC-027 \\
\hline
\end{tabular}

Ten of 16 paleomagnetic samples displayed normal primary remnant magnetizations (Table 1, Fig. 3). These samples include all those collected from below TGTL. The lowest samples were collected from a completely silt-filled, 5-meter high passage exposed in cross-section where it has been bisected by the active stream passage. The other normal polarity samples were collected from ancient silt banks in the upper level passages labeled in Fig. 2. These deposits are assumed to represent stream marginal deposition analogous to silt banks currently forming alongside subterranean Buckeye Creek.

(A) Paleomagnetism Sample BCC-016

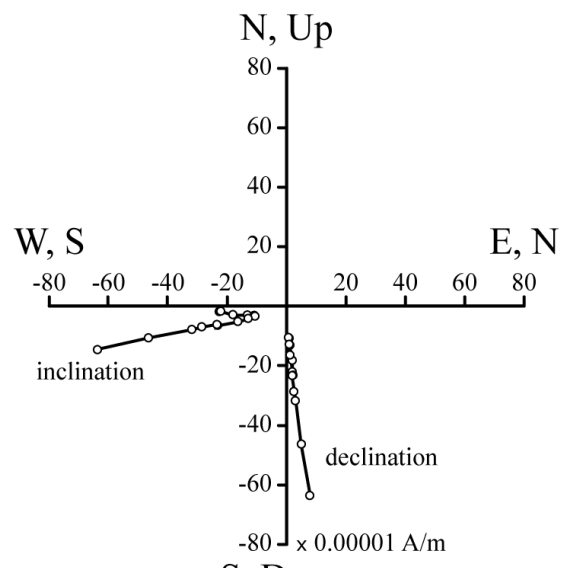

$\mathrm{S}$, Down
(B) Paleomagnetism Sample BCC-017

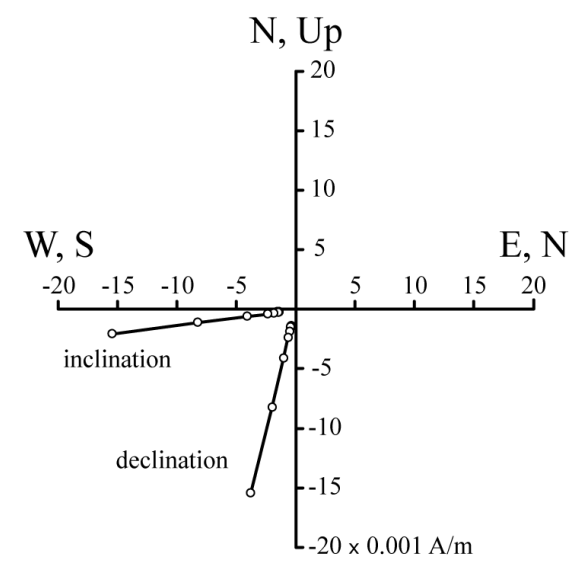

$\mathrm{S}$, Down
Fig. 3. Vector plots of paleomagnetism samples pBCC-016 and pBCC-017 as samples were demagnetized. Declinations and inclinations changed as samples were progressively demagnetized. The negative inclinations and southerly declinations are both consistent with the sampled cave sediments having been deposited during a period of reversed geomagnetism.

\section{Incision or groundwater table lowering rates}

The sampled stalagmites grew above the water table and point bar sedimentary structures suggest the sampled clastic cave sediments were deposited in a vadose or epiphreatic setting. Hence, sample ages and elevations constrain evolution of the local water table. The minimum stalagmite and paleomagnetic ages were converted to maximum possible groundwater table lowering rates using relative elevations. The latter were divided by the minimum ages and are reported in $\mathrm{m} \mathrm{Ma}^{-1}$ in Table 2. The table is arranged by relative elevations above the present cave stream with the highest samples at the top and lowest at the bottom. As calculated, the lowering rates are all $\leq 168 \mathrm{~m} \mathrm{Ma}^{-1}$. The latter value is of comparatively little value because it makes possible a wide range of incision rates. However, four rates are below $40 \mathrm{~m} \mathrm{Ma}^{-1}$, which narrows the range of possible rates to 0 to $40 \mathrm{~m} \mathrm{Ma}^{-1}$. The four rates are drawn from 3 of the 4 upper level tiers in BCC and were obtained using both of our methods: stalagmitic and paleomagnetic age dating. Agreement among these samples leads us to report a conservative incision rate estimate of $\leq 40 \mathrm{~m} \mathrm{Ma}^{-1}$ for Buckeye Creek. We note the real long-term lowering rate may be $\leq 35 \mathrm{~m} \mathrm{Ma}^{-1}$ (Table 2) and any periods of rapid lowering were of insufficient durations to be detectable by our methods. 
We assume Spring Creek has served as local base level during development of BCC and, as such, the $\mathrm{BCC}$ data records groundwater table lowering induced by Spring Creek. As such, the BCC data places constraints on the Spring Creek incision rates. Vadose deposition of the clastic sediments and stalagmites sets minimum elevations for Spring Creek at the times of deposition. Using the elevation differences between samples and the modern channel, the long-term Spring Creek incision rate must be $\leq 46 \mathrm{~m} \mathrm{Ma}^{-1}$ and $\leq 47 \mathrm{~m} \mathrm{Ma}^{-1}$, for the paleomagnetic and stalagmitic data, respectively. The very similar values may be a coincidence, but the similar results from paleomagnetostragraphy and stalagmite ages strengthen our confidence in the overall results.

\section{DISCUSSION}

Changes in the elevation of Buckeye Creek are the result of channel bed incision and capture of the cave stream by lower passages without complete incision of intervening rocks. These episodic piracies presumably arose as Spring Creek incision increased local hydraulic gradients and lowered the local water table. However, lowering of the water table and steepening of local hydraulic gradients could have been accomplished in two ways: (i) vertical incision of the Spring Creek surface channel with corresponding decreases in water table elevations; and (ii) lowering of local water tables as subsurface conduits developed below the Spring Creek streambed and fed down-gradient springs. There is reason to suspect both have been important controls on BCC development; groundwater table lowering rates are unlikely to be interchangeable with Spring Creek channel bed incision rates.

At described above, present day Spring Creek is perched upon interbedded limestones, siltstones, and shales in the vicinity of $\mathrm{BCC}$ and the stream is perennial with the groundwater table and streambed having the same elevation. Elsewhere along Spring Creek, the surface channel is still within the caveforming limestones of the Union Formation and an extensive vadose zone separates the surface channel from epiphreatic caves below. These caves include the Boartal Cave System whose normally air-filled passages are as much as 30 meters below the surface channel. The Buckeye and Spring creek incision rates we report are probably composites of surface channel incision and subsurface piracy if Spring Creek at BCC was partially or wholly diverted underground while the surface channel was within the Union Formation.

Conceptually, long-term incision rates in similarly well-developed fluviokarst may represent regional incision rates if the elevations of local base level springs are responding to regional downcutting. Here too, any calculated or observed rates will be affected by karst process, but if the time spans examined are sufficiently long they may extend beyond the onset of subsurface piracy and decoupling the water table from surface channel bed. Our record extends to $\geq 0.778 \mathrm{Ma}$ and may "average across" any such decoupling because BCC currently drains to the Spring Creek surface channel, as it would have before breaching the Union limestones near the elevation of the TGTL passage. Nonetheless, at present, we can only conclude the long-term incision rate of Spring Creek is $\leq 47 \mathrm{~m} \mathrm{Ma}^{-1}$ and acknowledge the rate is probably a composite effect of subsurface piracy and surface channel incision. We can state more confidently that subsurface Buckeye Creek has incised at a rate $\leq 40 \mathrm{~m} \mathrm{Ma}^{-1}$ over the last $\sim 1 \mathrm{Ma}$.

The degree to which incision rates reported from elsewhere in the Appalachian Mountains and Plateau are influenced by autogenic karst processes is unclear, as the possibility is not often discussed. However, episodic changes in base level caused by stream capture are common in many karst settings and long-term karst evolution is more complex than the evolution of a downcutting surface stream. But published cave-based studies have utilized deposits whose ages are in excess of 0.5 Ma and, presumably, the reported incision rates average across internal karst processes (e.g., Granger et al., 1997; Springer et al., 1997; Granger et al., 2001; Anthony \& Granger, 2007). The previously reported rates are below 60 $\mathrm{m} \mathrm{Ma}{ }^{-1}$ and our rates of $\leq 47 \mathrm{~m} \mathrm{Ma}^{-1}$ highlight the slow pace of incision in the region at million-year time scales. For comparison, Stock et al. (2005) used multiple dating methods to estimate incision rates within karstic canyons of the Sierra Nevada Mountains of California and report similarly low incision rates of $\sim 30$ to $50 \mathrm{~m} \mathrm{Ma}^{-1}$ despite active uplift. The similar incision rates despite such dissimilar geologies are not easily explained, although incision in the Sierra streams may be limited by the wearing away of highly resistant igneous and metamorphic rocks exposed downstream of the examined caves. In contrast, climatically driven changes in karst landscape processes have resulted in incision rates approaching $\sim 1200 \mathrm{~m} \mathrm{Ma}^{-1}$ in the European Alps where carbonates dominate the landscape and channel beds amid ongoing uplift and high local relief (Haeuselmann et al., 2007). A comparative lack of relief and uplift in the Appalachians must necessary decrease the energy available for incision and transport of sediment, thereby yielded low incision rates.

Bedrock streams predominate in southeastern West Virginia and many Appalachian rivers have comparatively steep gradients (Springer et al., 2003; Dortch et al., 2011). We suggest future work be focused on the mechanisms that preclude higher long-term incision rates, such as climate-driven aggradation/ degradation cycles (c.f., Springer et al., 2009). Incision rates are useful for interpreting erosion histories, but studying cyclic changes in fluvial and karst systems would improve our understanding of the fundamental processes at work during landscape evolution; we should examine both sides of the coin.

\section{ACKNOWLEDGMENTS}

The authors thank the late Gene Turner for access to Buckeye Creek Cave and permission to sample its stalagmites and cave sediments. We acknowledge the West Virginia Association for Cave Studies (http:/ / www. wvacs.org) for providing material support, including 
lodging, during our research. We thank three anonymous reviewers and the editor, B.P. Onac, for comments and guidance that improved the manuscript.

\section{REFERENCES}

Anthony D.M. \& Granger D.E., 2007 - A new chronology for the age of Appalachian erosional surfaces determined by cosmogenic nuclides in cave sediments. Earth Surface Processes and Landforms, 32: 874-887. http://dx.doi.org/10.1002/esp.1446

Broecker W.S., 1963 - A preliminary evaluation of uranium series inequilibrium as a tool for absolute age measurement on marine carbonates. Journal of Geophysical Research, 68: 2817-2834.

http://dx.doi.org/10.1029/JZ068i009p02817

Burbank D.W., Leland J., Fielding E., Anderson R.S., Brozovic N., Reid M.R. \& Duncan C., 1996 - Bedrock incision, rock uplift and threshold hillslopes in the northwestern Himalayas. Nature, 379: 505-510. http://dx.doi.org/10.1038/379505a0

Dasher G. \& Balfour W. (Eds.), 1994 - The caves and karst of the Buckeye Creek Basin. West Virginia Speleological Survey Bulletin 12, Barracksville, West Virginia, 236 pp.

Dasher G. \& Boyer D.G., 2001 - Recent Spring Creek area dye tracings, Greenbrier County, West Virginia. West Virginia Speleological Survey Monograph 2, 28 pp.

Dortch J.M., Dietsch C., Owen L.A., Caffee M.W. \& Ruppert K., 2011 - Episodic fluvial incision of rivers and rock uplift in the Himalaya and Transhimalaya. Journal of the Geological Society, 168: 783-804. http://dx.doi.org/10.1144/0016-76492009-158

Granger D.E., Fabel D. \& Palmer A.N., 2001 - PliocenePleistocene incision of the Green River, Kentucky, determined from radioactive decay of cosmogenic ${ }^{26} \mathrm{Al}$ and ${ }^{10} \mathrm{Be}$ in Mammoth Cave sediments. Geological Society of America Bulletin, 113: 825-836. http://dx.doi.org/10.1130/00167606(2001)113<0825:PPIOTG>2.0.CO;2

Granger D.E., Kirchner J.W. \& Finkel R.C., 1997 Quaternary downcutting rate of the New River, Virginia, measured from differential decay of cosmogenic ${ }^{26} \mathrm{Al}$ and ${ }^{10} \mathrm{Be}$ in cave-deposited alluvium. Geology, 25: 107-110. http://dx.doi.org/10.1130/00917613(1997)025<0107:QDROTN>2.3.CO;2

Haeuselmann P., Granger D.E., Jeannin P.-Y., Lauritzen S.-E., 2007 - Abrupt glacial valley incision at $0.8 \mathrm{Ma}$ dated from cave deposits in Switzerland. Geology 35: 143-146. http://dx.doi.org/10.1130/G23094A

Hardt B., Rowe H.D., Springer G.S., Cheng H. \& Edwards R.L., 2010 - The seasonality of east central North American precipitation based on three coeval Holocene speleothems from southern West Virginia. Earth and Planetary Science Letters, 295: 342-348.

http://dx.doi.org/10.1016/j.eps1.2010.04.002

Jones W., 1997 - Karst hydrology atlas of West Virginia. Karst Waters Institute Special Publication 4, 124 pp.

Edwards R.L., Chen H. \& Wasserburg G.J., $1987-{ }^{238} U \_234 U-$ ${ }^{230} \mathrm{Th}^{-232} \mathrm{Th}$ systematics and the precise measurement of time over the past 500,000 years. Earth and Planetary Science Letters, 81: 175-192.

http://dx.doi.org/10.1016/0012-821X(87)90154-3
Miller S.R., Sak P.B., Kirby E. \& Bierman P.R., 2013 - Neogene rejuvenation of central Appalachian topography: Evidence for differential rock uplift from stream profiles and erosion rates. Earth and Planetary Science Letters, 369-370: 1-12.

http://dx.doi.org/10.1016/j.eps1.2013.04.007

Sasowsky I.D., 1998 - Determining the age of what is not there. Science, 279: 1874-1874.

http://dx.doi.org/10.1126/science.279.5358.1874

Sasowsk I.D., White W.B. \& Schmidt V.A., 1995 Determination of stream-incision rate in the Appalachian plateaus by using cave-sediment magnetostratigraphy. Geology, 23: 415-418.

http://dx.doi.org/10.1130/00917613(1995)023<0415:DOSIRI>2.3.CO;2

Schmidt V.A., 1982 - Magnetostratigraphy of Sediments in Mammoth Cave, Kentucky. Science, 217: 827-829. http://dx.doi.org/10.1126/science.217.4562.827

Shen C.-C., Edwards L.R., Cheng H., Dorale J.A., Thomas R.B., Moran B.S., Weinstein S.E. \& Edmonds H.N., 2002 - Uranium and thorium isotopic and concentration measurements by magnetic sector inductively coupled plasma mass spectrometry. Chemical Geology, 185: $165-178$.

http://dx.doi.org/10.1016/S0009-2541(01)00404-1

Singer B.S. \& Pringle M.S., 1996 - Age and duration of the Matuyama-Brunhes geomagnetic polarity reversal from ${ }^{40} \mathrm{Ar} /{ }^{39} \mathrm{Ar}$ incremental heating analyses of lavas. Earth and Planetary Science Letters, 139: 47-61. http://dx.doi.org/10.1016/0012-821X(96)00003-9

Springer G.S., 2004 - A pipe-based, first approach to modeling closed conduit flow in caves. Journal of Hydrology, 289: 178-189.

http://dx.doi.org/10.1016/j.jhydrol.2003.11.020

Springer G.S., Rowe H.D., Hardt B., Cocina F.G., Edwards R.L. \& Cheng H., 2009 - Climate driven changes in river channel morphology and base level during the Holocene and Late Pleistocene of Southeastern West Virginia. Journal of Cave and Karst Studies, 71: 121-129.

Springer G.S., Kite J.S., \& Schmidt V.A., 1997 - Cave sedimentation, genesis, and erosional history in the Cheat River Canyon, West Virginia. Geological Society of America Bulletin, 109: 524-532.

http://dx.doi.org/10.1130/00167606(1997)109<0524:CSGAEH>2.3.CO;2

Springer G.S., Wohl E.E., Foster J.A. \& Boyer D.G., 2003 - Testing for reach-scale adjustments of hydraulic variables to soluble and insoluble strata: Buckeye Creek and Greenbrier River, West Virginia. Geomorphology 56: 201-217. http://dx.doi.org/10.1016/S0169-555X(03)00079-5

Stock G.M., Granger D.E., Sasowsky I.D., Anderson R.S. \& Finkel R.C., 2005 - Comparison of U-Th, paleomagnetism, and cosmogenic burial methods for dating caves: Implications for landscape evolution studies. Earth and Planetary Science Letters, 236: 388-403. http://dx.doi.org/10.1016/j.eps1.2005.04.024

Yang G., Zhang X., Tian M., Ping Y., Chen A., Ge Z., Ni Z. \& Yang Z., 2011 - Geomorphological and sedimentological comparison of fluvial terraces and karst caves in Zhangjiajie, northwest Hunan, China: an archive of sandstone landform development. Environment and Earth Sciences, 64: 671-683. http://dx.doi.org/10.1007/s12665-010-0887-6 